\title{
Cu-Based Bulk Glass Formation in the Cu-Zr-Ga Alloy System and Their Mechanical Properties
}

\author{
Wei Zhang ${ }^{1}$ and Akihisa Inoue ${ }^{2}$ \\ ${ }^{1}$ Japan Science and Technology Agency, Sendai 982-0807, Japan \\ ${ }^{2}$ Institute for Materials Research, Tohoku University, Sendai 980-8577, Japan
}

\begin{abstract}
The thermal stability, glass-forming ability (GFA) and mechanical properties of a new Cu-based glassy alloy in $\mathrm{Cu}-\mathrm{Zr}$-Ga ternary system have been investigated. The supercooled liquid region $\Delta T_{\mathrm{x}}\left(=T_{\mathrm{x}}-T_{\mathrm{g}}\right)$ exceeding $40 \mathrm{~K}$ and reduced glass transition temperature $\left(T_{\mathrm{g}} / T_{\mathrm{l}}\right)$ above 0.59 are obtained simultaneously in the composition range from 2.5 to $7.5 \% \mathrm{Ga}$ and 37.5 to $42.5 \% \mathrm{Zr}$, and the highest $T_{\mathrm{g}} / T_{1}$ is 0.62 for $\mathrm{Cu}_{52.5} \mathrm{Zr}_{42.5} \mathrm{Ga}_{5}$ and $\mathrm{Cu}_{55} \mathrm{Zr}_{40} \mathrm{Ga}_{5}$ alloys. The $\mathrm{Cu}$-based $\mathrm{Cu}-\mathrm{Zr}-\mathrm{Ga}$ glassy alloys are formed in a rod form with a diameter up to $2.0 \mathrm{~mm}$ by the copper mold casting. The bulk glassy alloys exhibit good mechanical properties of 550-580 for Vicker's hardness $\left(H_{\mathrm{v}}\right)$, $105-111 \mathrm{GPa}$ for Young's modulus $(E), 1910-2130 \mathrm{MPa}$ for compressive fracture strength $\left(\sigma_{\mathrm{c}, \mathrm{f}}\right)$, and $0.2-0.5 \%$ for plastic elongation. The GFA of Cu-based Cu$\mathrm{Zr}$-Ga glassy alloys is more closely related to $T_{\mathrm{g}} / T_{1}$ values rather than $\Delta T_{\mathrm{x}}$. The present new Cu-based bulk glassy alloys are expected to be developed as another type of bulk structural material with higher strength combined with good ductility.
\end{abstract}

(Received October 27, 2003; Accepted December 12, 2003)

Keywords: copper-based alloy, bulk glassy alloy, casting, supercooled liquid region, reduced glass transition temperature, mechanical properties

\section{Introduction}

It is known that amorphous alloys have characteristic physical and chemical properties such as high strength, high corrosion resistance and good soft magnetic properties, which are significantly different from the corresponding crystalline alloys. ${ }^{1)}$ However, the requirement of rapid solidification has lead to strict limitation of their material shape to ribbons, wires and powders and its limitation has restricted further extension of their application fields. Since the findings of glassy-type alloys with a large supercooled liquid region in $\mathrm{Mg}-\mathrm{Ce}-\mathrm{Ni}^{2}$ and $\mathrm{La}-\mathrm{Al}-\mathrm{Ni}^{3)}$ systems, followed by the successes of producing bulk glassy alloys in the $\mathrm{Ln}^{-}{ }^{4}$ ( $\mathrm{Ln}=$ lanthanide metals) and $\left.\mathrm{Mg}_{-}{ }^{5}\right)$ based systems by the copper mold casting method, much attention has been paid to the development of new alloy systems with high glassforming ability (GFA). As a result, bulk glassy alloy systems have been widely extended to $\mathrm{Zr}-,{ }^{6,7)} \mathrm{Fe}-,{ }^{8)} \mathrm{Pd}-\mathrm{Cu}-,{ }^{9)} \mathrm{Co}-,{ }^{10)}$ $\mathrm{Cu}-\mathrm{Ti}^{-}{ }^{11)} \mathrm{Ni}-\mathrm{Zr}-{ }^{12}$ ) and $\mathrm{Ni}-\mathrm{Nb}^{13-17)}$ based alloys. However, there had been no data on the formation of $\mathrm{Cu}$-based bulk glassy alloys which were defined as the alloy containing more than 50 at\% $\mathrm{Cu}$. In 2001, we have reported that the $\mathrm{Cu}$-based bulk glassy alloys in $\mathrm{Cu}-\mathrm{Zr}-\mathrm{Ti}$ and $\mathrm{Cu}-\mathrm{Hf}-\mathrm{Ti}$ ternary systems are formed in the thickness range up to of $4 \mathrm{~mm}$, and their alloys possess high strength and good ductility. ${ }^{18-20)}$ These mechanical properties are considerably better then those for Zr-based bulk glassy alloys. ${ }^{21,22)}$ Although a number of $\mathrm{Cu}$ based bulk glassy alloys have been developed in $\mathrm{Cu}-(\mathrm{Zr}, \mathrm{Hf})-$ $\mathrm{Ti}^{23)} \mathrm{Cu}-\mathrm{Zr}-\mathrm{Ti}-\mathrm{Be},{ }^{24)} \mathrm{Cu}-\mathrm{Zr}-\mathrm{Ti}-(\mathrm{Fe}, \mathrm{Co}, \mathrm{Ni})^{25)}$ and $\mathrm{Cu}-(\mathrm{Zr}$ or $\mathrm{Hf})-\mathrm{Ti}-(\mathrm{Nb}, \mathrm{Ta})^{26-28)}$ systems, it is important to search for a new ternary $\mathrm{Cu}$-based bulk glassy alloys for future development as a high strength materials. Recently, we have also reported that addition of $\mathrm{Al}$ to $\mathrm{Cu}-\mathrm{Zr}$ alloys was effective for the increase in GFA as well as for the stabilization of supercooled liquid. The $\mathrm{Cu}$-based bulk glassy alloys of $3 \mathrm{~mm}$ in thickness are formed in $\mathrm{Cu}-\mathrm{Zr}-\mathrm{Al}$ ternary system and they also exhibit good mechanical properties. ${ }^{29)}$ Considering the similarities of atomic radius and atomic electronic negativity between $\mathrm{Al}$ and $\mathrm{Ga}$ elements belonging to the same group number in the periodic table, similar bulk glassy alloys are also expected to be formed in $\mathrm{Cu}-\mathrm{Zr}-\mathrm{Ga}$ system. This paper intends to present the composition dependence of thermal stability of the glassy $\mathrm{Cu}-\mathrm{Zr}-\mathrm{Ga}$ alloys, and the maximum thickness, mechanical properties and fracture behavior of the $\mathrm{Cu}$-based bulk glassy alloys. The reason for the high glassforming ability in the ternary system is also discussed.

\section{Experimental Procedure}

Multi-component Ni-based alloy ingots with nominal composition of $\mathrm{Cu}_{100-x-y} \mathrm{Zr}_{x} \mathrm{Ga}_{y}$ were prepared by arc melting the mixtures of pure $\mathrm{Cu}, \mathrm{Zr}$ and $\mathrm{Ga}$ metals in a Tigettered argon atmosphere. The purity of metals was over 99.9 mass \%. Alloy ingots were re-melted four times to ensure chemical homogeneity. The mass losses were measured for each ingot after melting and were less than 0.1 mass $\%$. The glassy alloy was produced by copper mold casting for bulk cylindrical rods with diameters up to $3 \mathrm{~mm}$ and by melt spinning for ribbons with a cross section of $0.02 \times 1.5 \mathrm{~mm}^{2}$. The glassy phase was identified by X-ray diffraction and thermal stability was examined by differential scanning calorimetry (DSC) at a heating rate of $0.67 \mathrm{~K} / \mathrm{s}$. The melting and liquidus temperatures were measured with a differential thermal analyzer (DTA) at a heating rate of $0.17 \mathrm{~K} / \mathrm{s}$. Vicker's hardness was measured using a microhardness tester under a load of $50 \mathrm{~g}$. Mechanical properties were measured with an Instron testing machine. The gauge dimension of specimens was 1.5 or $2 \mathrm{~mm}$ in diameter and 3 or $4 \mathrm{~mm}$ in height for compressive test, and the strain rate was $5 \times 10^{-4} \mathrm{~s}^{-1}$. The fracture surface was examined by scanning electron microscopy (SEM). 


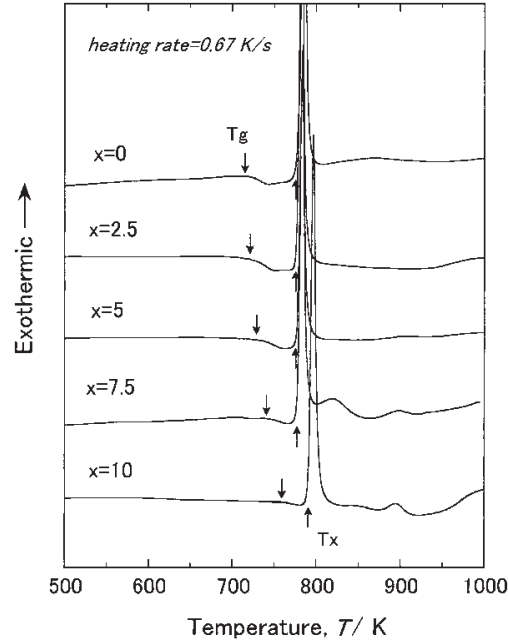

Fig. 1 DSC curves of melt-spun $\mathrm{Cu}_{60-x} \mathrm{Zr}_{40} \mathrm{Ga}_{x}$ $(x=0$ to 10 at $\%)$ glassy alloys.

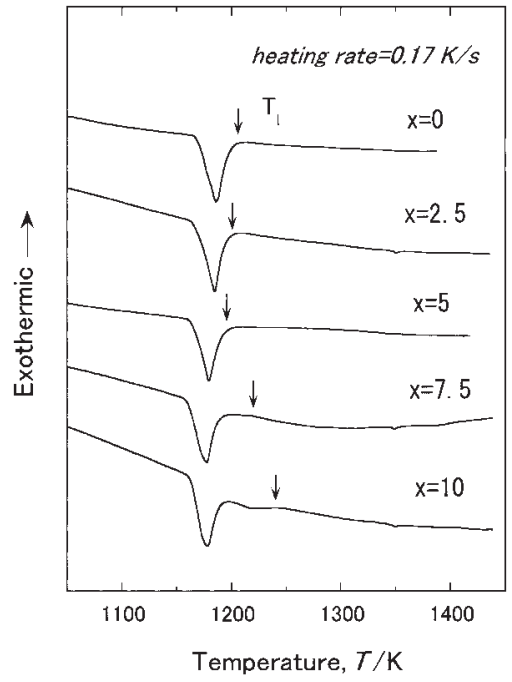

Fig. 2 DTA curves of melt-spun $\mathrm{Cu}_{60-x} \mathrm{Zr}_{40} \mathrm{Ga}_{x}$ $(x=0$ to 10 at $\%)$ glassy alloys.

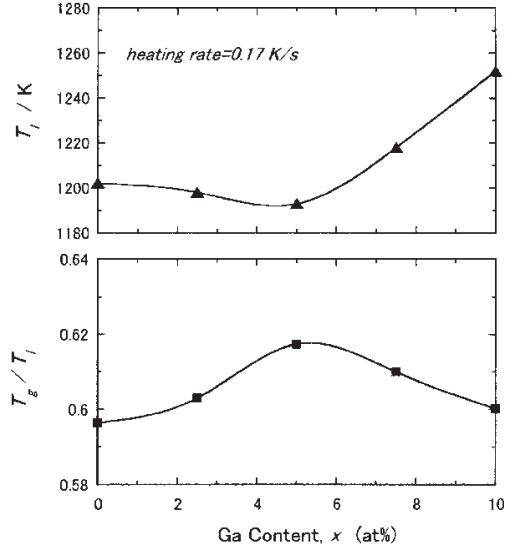

Fig. 3 Changes in the liquidus temperature $\left(T_{1}\right)$ and reduced glass transition temperature $\left(T_{\mathrm{g}} / T_{1}\right)$ as a function of $\mathrm{Ga}$ content for melt-spun $\mathrm{Cu}_{60-x} \mathrm{Zr}_{40} \mathrm{Ga}_{x}(x=0$ to 10 at $\%$ ) glassy alloys.

\section{Results and Discussion}

The X-ray diffraction patterns showed that the melt-spun ribbons of the $\mathrm{Cu}_{100-x-y} \mathrm{Zr}_{x} \mathrm{Ga}_{y}$ ( $x=30$ to $60, x=0$ to 10 ) alloys are composed of a single glassy phase. Figure 1 shows DSC curves of the melt-spun $\mathrm{Cu}_{60-x} \mathrm{Zr}_{40} \mathrm{Ga}_{x}(x=0$ to 10$)$ glassy alloys. As marked with the glass transition temperature $\left(T_{\mathrm{g}}\right)$ and crystallization temperature $\left(T_{\mathrm{x}}\right)$, it is noticed that the glass transition and supercooled liquid region $\left(\Delta T_{\mathrm{x}}=T_{\mathrm{x}}-T_{\mathrm{g}}\right)$ are observed in the Ga concentration range of 0 to $10 \mathrm{at} \%$. As the $\mathrm{Ga}$ content increases, $T_{\mathrm{g}}$ and $T_{\mathrm{x}}$ gradually increases, and the increases ratio is considerably larger for $T_{\mathrm{g}}$, resulting in the $\Delta T_{\mathrm{x}}$ gradually decreases from $60 \mathrm{~K}$ at $x=0$ to $28 \mathrm{~K}$ at $x=10$. Figure 2 shows DTA curves of the $\mathrm{Cu}_{60-x} \mathrm{Zr}_{40} \mathrm{Ga}_{x}$ ( $x=0$ to 10 ) alloys. The endothermic peak due to melting is observed for all the alloys and the melting reaction appears to occur through a single stage for the $x=0$ to 5 alloys. Based on the data shown in Fig. 2, the liquidus temperature $\left(T_{1}\right)$ and the reduced glass transition temperature $\left(T_{\mathrm{g}} / T_{1}\right)$ of the $\mathrm{Cu}_{60-x} \mathrm{Zr}_{40} \mathrm{Ga}_{x}$ ( $x=0$ to 10$)$ alloys were plotted as a function of Ga content in Fig. 3. It is clearly seen that $T_{1}$ shows a minimum value of $1193 \mathrm{~K}$ for $x=5$ alloy, indicate that a eutectic composition in the ternary system is located in the vicinity of $x=5$. As a result, the $5 \% \mathrm{Ga}$ alloy exhibits a maximum $T_{\mathrm{g}} / T_{1}$ of 0.617 . It is thus concluded that the addition of $5 \% \mathrm{Ga}$ to $\mathrm{Cu}-\mathrm{Zr}$ glassy alloys is effective for an increase in $T_{\mathrm{g}} / T_{1}$.

We further examined the effect of $\mathrm{Zr}$ content on the thermal stability of supercooled liquid in the alloy series of $\mathrm{Cu}_{95-x} \mathrm{Zr}_{x} \mathrm{Ga}_{5}$. As shown for the DSC curves of the $\mathrm{Cu}_{95-x} \mathrm{Zr}_{x} \mathrm{Ga}_{5}(x=35$ to 50$)$ alloys in Fig. 4, the glass transition phenomenon in conjunction with a supercooled liquid region is observed in a wide $\mathrm{Zr}$ content range of 35 to 50 at $\%$. The $T_{\mathrm{g}}$ and $T_{\mathrm{x}}$ decrease monotonously with increasing $\mathrm{Zr}$ content, and the $\Delta T_{\mathrm{x}}$ value increases monotonously from 39 to $57 \mathrm{~K}$ with increasing $\mathrm{Zr}$ content to 50 at $\%$. Figure 5 shows the $T_{1}$ and the $T_{\mathrm{g}} / T_{1}$ as a function of $\mathrm{Zr}$ content for the $\mathrm{Cu}_{95-x} \mathrm{Zr}_{x} \mathrm{Ga}_{5}$ ( $x=35$ to 50 ) glassy alloys. The lowest $T_{1}$ at about $42.5 \% \mathrm{Zr}$ causes the highest $T_{\mathrm{g}} / T_{1}$ of 0.618 , and the further increase in $\mathrm{Zr}$ content results in a significant decrease in $T_{\mathrm{g}} / T_{1}$. Here, it is noticed that the large $\Delta T_{\mathrm{x}}$ exceeding $40 \mathrm{~K}$ and high $T_{\mathrm{g}} / T_{1}$ over 0.59 are simultaneously obtained in the $\mathrm{CuZr}_{37.5-42.5} \mathrm{Ga}_{2.5-7.5}$ alloys, indicating that the $\mathrm{Cu}$-based ternary alloy has high thermal stability of supercooled liquid and high GFA. ${ }^{30,31)}$

Figure 6 shows X-ray diffraction patterns of the cast rods of composition $\mathrm{Cu}_{52.5} \mathrm{Zr}_{42.5} \mathrm{Ga}_{5}, \mathrm{Cu}_{55} \mathrm{Zr}_{40} \mathrm{Ga}_{5}$, $\mathrm{Cu}_{57.5} \mathrm{Zr}_{40} \mathrm{Ga}_{2.5}$, and $\mathrm{Cu}_{52.5} \mathrm{Zr}_{40} \mathrm{Ga}_{7.5}$. The rods have diameters of 1.5 and $2.0 \mathrm{~mm}$, respectively. No distinct crystalline peaks are observed for the all samples, indicating the formation of a glassy phase without crystallinity in the diameter range up to $2.0 \mathrm{~mm}$. From the DSC curves of the cast glassy alloy rods with diameters of 1.5 and $2.0 \mathrm{~mm}$, it was confirmed that the $T_{\mathrm{g}}, T_{\mathrm{x}}$ and heat of crystallization were nearly the same among the bulk and ribbon samples, being consistent with the result obtained by X-ray diffraction. Table 1 summarizes the thermal properties and glass-forming ability of the $\mathrm{Cu}-\mathrm{Zr}$-Ga glassy alloys. As described above, the $\mathrm{Cu}-\mathrm{Zr}-\mathrm{Ga}$ glassy alloys exhibited a high thermal stability of the supercooled liquid and the high GFA leading to the formation of the bulk glassy rods with diameters up to $2.0 \mathrm{~mm}$. The reason for the larger $\Delta T_{\mathrm{x}}$ and high $T_{\mathrm{g}} / T_{1}$ for the $\mathrm{Cu}-\mathrm{Zr}-\mathrm{Ga}$ glassy alloy is discussed in the framework of the three empirical rules ${ }^{30,31)}$ for the achievement of high GFA. The three empirical rules are (1) multi-component consisting of more than three elements, (2) significant atomic size mismatches among the main constituent elements, and (3) suitable negative heats of mixing their elements. The atomic sizes change in the order of $\mathrm{Zr}>\mathrm{Ga}>\mathrm{Cu}$ and the atomic size ratio is 1.25 for $\mathrm{Zr} / \mathrm{Cu}, 1.14$ for $\mathrm{Zr} / \mathrm{Ga}$ and 1.10 for $\mathrm{Ga} / \mathrm{Cu}^{32}$ ) Furthermore, the heats of mixing have been estimated to be $-23 \mathrm{~kJ} / \mathrm{mol}$ for $\mathrm{Cu}-\mathrm{Zr},-40 \mathrm{~kJ} / \mathrm{mol}$ for $\mathrm{Zr}-\mathrm{Ga}$ and $-1 \mathrm{~kJ} / \mathrm{mol}$ for $\mathrm{Cu}-\mathrm{Ga} .{ }^{33)}$ Thus, the data on the atomic size ratios and the heats of mixing indicate that the present $\mathrm{Cu}$-based alloy system satisfy the three empirical rules, leading to a high thermal stability of the supercooled liquid against crystallization and the high GFA. The mechanism for the stabilization of supercooled liquid for the alloys satisfying the three 


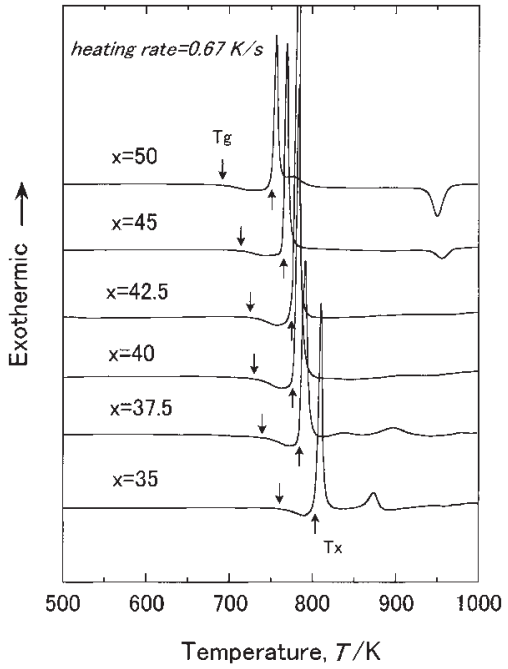

Fig. 4 DSC curves of melt-spun $\mathrm{Cu}_{95-x} \mathrm{Zr}_{x} \mathrm{Ga}_{5}(x=35$ to 50 at $\%)$ glassy alloys.
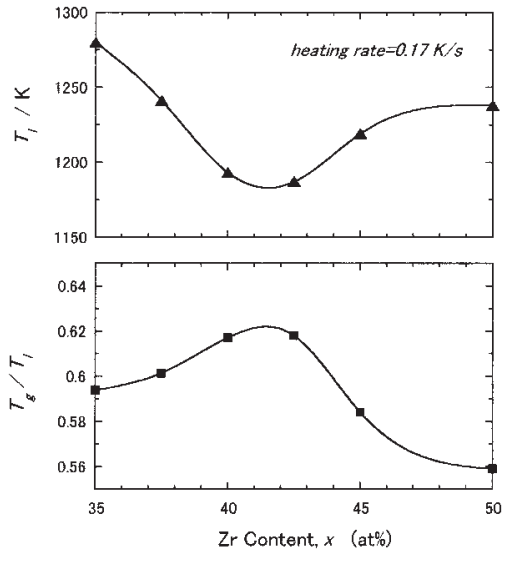

Fig. 5 Changes in the liquidus temperature $\left(T_{1}\right)$ and reduced glass transition temperature $\left(T_{\mathrm{g}} / T_{1}\right)$ as a function of $\mathrm{Zr}$ content for melt-spun $\mathrm{Cu}_{95-x} \mathrm{Zr}_{x} \mathrm{Ga}_{5}$ $(x=35$ to 50 at $\%)$ glassy alloys.

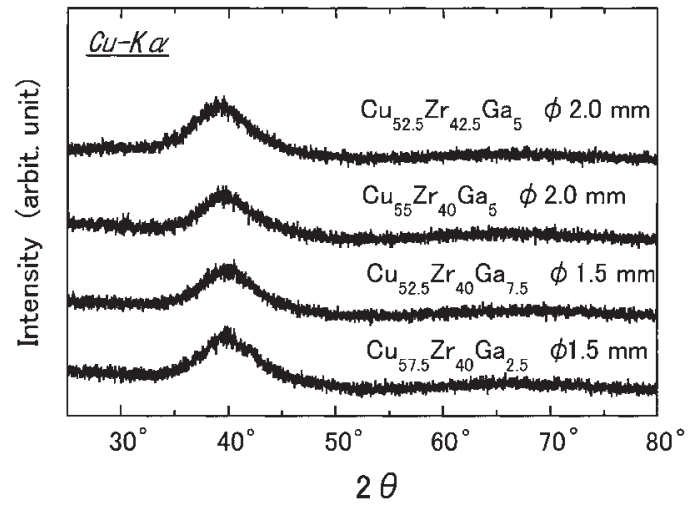

Fig. 6 X-ray diffraction pattern of the cast $\mathrm{Cu}-\mathrm{Zr}$-Ga alloy rod with the diameters of 1.5 and $2.0 \mathrm{~mm}$.
Table 1 Thermal stability and critical sample thickness $\left(t_{\mathrm{c}}\right)$ of $\mathrm{Cu}-\mathrm{Zr}-\mathrm{Ga}$ glassy alloys.

\begin{tabular}{ccccccc}
\hline $\begin{array}{c}\text { Composition } \\
(\text { at\% })\end{array}$ & $\begin{array}{c}T_{\mathrm{g}} \\
(\mathrm{K})\end{array}$ & $\begin{array}{c}T_{\mathrm{x}} \\
(\mathrm{K})\end{array}$ & $\begin{array}{c}\Delta T_{\mathrm{x}} \\
(\mathrm{K})\end{array}$ & $\begin{array}{c}T_{\mathrm{l}} \\
(\mathrm{K})\end{array}$ & $T_{\mathrm{g}} / T_{1}$ & $\begin{array}{c}t_{\mathrm{c}} \\
(\mathrm{mm})\end{array}$ \\
\hline $\mathrm{Cu}_{52.5} \mathrm{Zr}_{42.5} \mathrm{Ga}_{5}$ & 733 & 777 & 44 & 1187 & 0.618 & 2.0 \\
$\mathrm{Cu}_{55} \mathrm{Zr}_{40} \mathrm{Ga}_{5}$ & 736 & 779 & 43 & 1193 & 0.617 & 2.0 \\
$\mathrm{Cu}_{42.5} \mathrm{Zr}_{40} \mathrm{Ga}_{7.5}$ & 744 & 777 & 33 & 1218 & 0.610 & 1.5 \\
$\mathrm{Cu}_{57.5} \mathrm{Zr}_{40} \mathrm{Ga}_{2.5}$ & 723 & 776 & 53 & 1198 & 0.604 & 1.5 \\
$\mathrm{Cu}_{57.5} \mathrm{Zr}_{37.5} \mathrm{Ga}_{5}$ & 745 & 785 & 40 & 1241 & 0.601 & 1.0 \\
$\mathrm{Cu}_{55} \mathrm{Zr}_{42.5} \mathrm{Ga}_{2.5}$ & 709 & 762 & 53 & 1199 & 0.591 & 1.0 \\
\hline
\end{tabular}

empirical rules has been described in previous papers and reviews. ${ }^{30,31)}$ It is also noticed that the $\Delta T_{\mathrm{x}}, T_{\mathrm{g}} / T_{1}$ and critical sample thickness $\left(t_{\mathrm{c}}\right)$ of the $\mathrm{Cu}-\mathrm{Zr}-\mathrm{Ga}$ bulk glassy alloys are $33-53 \mathrm{~K}, 0.59-0.62$ and $1.0-2.0 \mathrm{~mm}$ respectively. The relation among $\Delta T_{\mathrm{x}}, T_{\mathrm{g}} / T_{1}$ and $t_{\mathrm{c}}$ for the Cu-based ternary glassy alloys, indicates that the GFA is not directly related to $\Delta T_{\mathrm{x}}$ and depends strongly on $T_{\mathrm{g}} / T_{1}$.

Figure 7 shows the compressive stress-strain curve of the glassy alloys rods. It is seen that the glassy alloys exhibit high fracture strengths of above $1900 \mathrm{MPa}$ and the distinct plastic

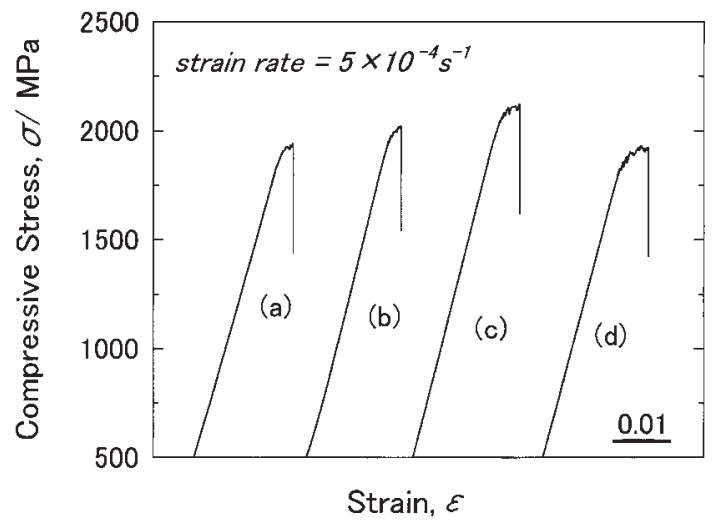

Fig. 7 Compressive stress-elongation curves of cast (a) $\mathrm{Cu}_{52.5} \mathrm{Zr}_{42.5} \mathrm{Ga}_{5}$, (b) $\mathrm{Cu}_{55} \mathrm{Zr}_{40} \mathrm{Ga}_{5}$, (c) $\mathrm{Cu}_{52.5} \mathrm{Zr}_{40} \mathrm{Ga}_{7.5}$ and (d) $\mathrm{Cu}_{57.5} \mathrm{Zr}_{40} \mathrm{Ga}_{2.5}$ glassy alloy rod with the diameters of 1.5 and $2.0 \mathrm{~mm}$.
Table 2 The mechanical properties of $\mathrm{f} \mathrm{Cu-Zr-Ga}$ bulk glassy alloys.

\begin{tabular}{lcccc}
\hline $\begin{array}{c}\text { Composition } \\
(\mathrm{at} \%)\end{array}$ & $\begin{array}{c}\sigma_{\mathrm{c}, \mathrm{f}} \\
(\mathrm{MPa})\end{array}$ & $\begin{array}{c}E \\
(\mathrm{GPa})\end{array}$ & $\begin{array}{c}\varepsilon_{\mathrm{c}, \mathrm{p}} \\
(\%)\end{array}$ & $H_{\mathrm{V}}$ \\
\hline $\mathrm{Cu}_{52.5} \mathrm{Zr}_{42.5} \mathrm{Ga}_{5}$ & 1940 & 105 & 0.2 & 552 \\
$\mathrm{Cu}_{55} \mathrm{Zr}_{40} \mathrm{Ga}_{5}$ & 2025 & 109 & 0.2 & 565 \\
$\mathrm{Cu}_{42.5} \mathrm{Zr}_{40} \mathrm{Ga}_{7.5}$ & 2130 & 111 & 0.3 & 581 \\
$\mathrm{Cu}_{57.5} \mathrm{Zr}_{40} \mathrm{Ga}_{2.5}$ & 1910 & 105 & 0.5 & 547 \\
\hline
\end{tabular}

strains over $0.1 \%$. Table 2 summarizes the mechanical properties of the $\mathrm{Cu}-\mathrm{Zr}-\mathrm{Ga}$ bulk glassy alloy rods. The $\mathrm{Cu}-\mathrm{Zr}-$ Ga bulk glassy alloys possess good mechanical properties, i.e., compressive fracture strength $\left(\sigma_{\mathrm{c}, \mathrm{f}}\right)$ of $1910-2130 \mathrm{MPa}$, Young's modulus $(E)$ of $105-111 \mathrm{GPa}$, compressive plastic elongation $\left(\varepsilon_{\mathrm{c}, \mathrm{p}}\right)$ of $0.2-0.5 \%$ and Vickers hardness $\left(H_{\mathrm{V}}\right)$ of 547-581. It is noticed that the $\sigma_{\mathrm{c}, \mathrm{f}}, E$ and $H_{\mathrm{V}}$ show a distinct dependence, i.e., a gradual decrease in these strength values with decreasing $T_{\mathrm{g}}$. It is interpreted that the $T_{\mathrm{g}}$ of the glassy alloys reflects the bonding force among the constituent elements. ${ }^{34)}$ The fracture behavior and fracture surface appearance are exemplified in Fig. 8 for the $\mathrm{Cu}_{52.5} \mathrm{Ga}_{42.5} \mathrm{Ga}_{5}$ glassy alloy rod. The fracture occurs along the maximum

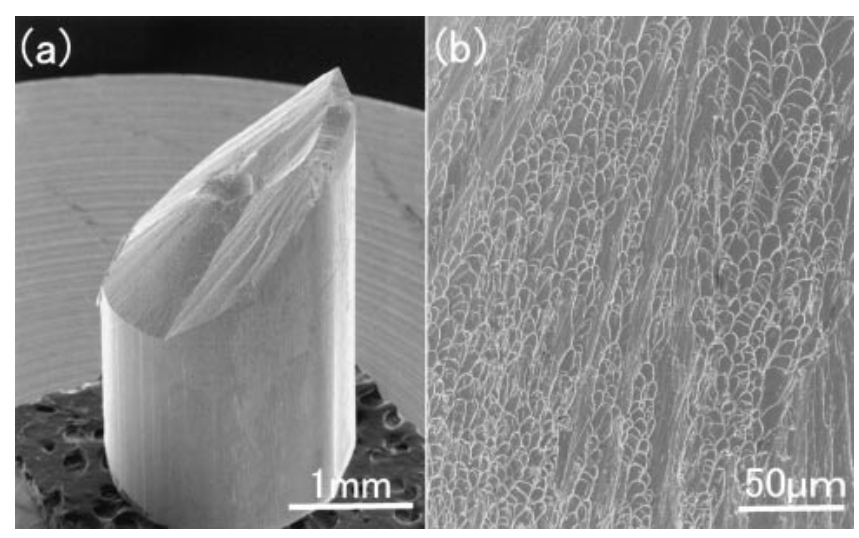

Fig. 8 Fracture surface appearance of the cast $\mathrm{Cu}_{52.5} \mathrm{Zr}_{42.5} \mathrm{Ga}_{5}$ glassy alloy rod with a diameter of $2.0 \mathrm{~mm}$. 
shear plane which is declined by about 45 degrees to the direction of applied load (Fig. 8(a)), and the fracture surface consists mainly of well developed vein pattern (Fig. 8(b)). The feature of the fracture morphology is the same as that for the other bulk glassy alloys indicates that the present $\mathrm{Cu}$ based bulk glassy alloys with much higher fracture strength are in a ductile state.

\section{Summary}

We examined the effect of Ga addition on the glassforming ability, thermal stability and mechanical properties of $\mathrm{Cu}-\mathrm{Zr}$ glassy alloys, with the aim of synthesizing a bulk glassy alloy with high strength in the $\mathrm{Cu}$-based $\mathrm{Cu}-\mathrm{Zr}-\mathrm{Ga}$ ternary system. The results obtained are summarized as follows.

(1) In the $\mathrm{Cu}_{60} \mathrm{Zr}_{40-x} \mathrm{Ga}_{x}$ glassy alloys $(x=0-10), T_{\mathrm{g}}$ and $T_{\mathrm{x}}$ increase monotonously with increasing Ga content, while the $\Delta T_{\mathrm{x}}$ decreases monotonously from $60 \mathrm{~K}$ at $0 \% \mathrm{Ga}$ to $28 \mathrm{~K}$ at $10 \% \mathrm{Ga}$. The $T_{\mathrm{g}} / T_{1}$ shows a maximum value of 0.617 at $5 \% \mathrm{Ga}$ because of the minimum $T_{1}$ value of $1193 \mathrm{~K}$ at $5 \% \mathrm{Ga}$. (2) The $T_{\mathrm{g}}$ and $T_{\mathrm{x}}$ of the $\mathrm{Cu}_{95-x} \mathrm{Zr}_{x} \mathrm{Ga}_{5}$ glassy alloys decrease monotonously with increasing $\mathrm{Zr}$ content while the $\Delta T_{\mathrm{x}}$ increases monotonously. The $\Delta T_{\mathrm{x}}$ is in the range from $39 \mathrm{~K}$ at $35 \% \mathrm{Zr}$ to $57 \mathrm{~K}$ at $50 \% \mathrm{Zr}$. The $T_{1}$ shows a minimum of $1187 \mathrm{~K}$ at $42.5 \% \mathrm{Zr}$, leading to a maximum $T_{\mathrm{g}} / T_{1}$ of 0.618 at $42.5 \% \mathrm{Zr}$.

(3) Bulk glassy alloy rod with diameters up to $2.0 \mathrm{~mm}$ was formed for $\mathrm{Cu}_{52.5} \mathrm{Zr}_{42.5} \mathrm{Ga}_{5}$ and $\mathrm{Cu}_{50} \mathrm{Zr}_{40} \mathrm{Ga}_{5}$ alloy by copper mold casting. The glass-forming ability of $\mathrm{Cu}$-based $\mathrm{Cu}-\mathrm{Zr}$ Ga alloys is more closely related to $T_{\mathrm{g}} / T_{1}$ values rather than $\Delta T_{\mathrm{x}}$.

(4) The bulk glassy alloy exhibits good mechanical properties, i.e., Vicker's hardness of 547-581, Young's modulus of $105-111 \mathrm{GPa}$, compressive fracture strength of 1910 $2130 \mathrm{MPa}$, and plastic elongation of $0.2-0.5 \%$.

\section{REFERENCES}

1) F. E. Luborsky(Ed.): Amorphour Metallic Alloys, (Butterworths, London, 1983) pp. 1-7.

2) A. Inoue, K. Ohtera, K. Kita and T. Masumoto: Jpn. J. Appl. Phys. 27 (1988) L2248-L2251.
3) A. Inoue, T. Zhang and T. Masumoto: Mater. Trans., JIM 30 (1989) 965-972.

4) A. Inoue, T. Zhang and T. Masumoto: Mater. Trans., JIM 31 (1990) $425-428$.

5) A. Inoue, A. Kato, T. Zhang, S. G. Kim and T. Masumoto: Mater. Trans., JIM 32 (1991) 609-616.

6) A. Inoue, T. Zhang and T. Masumoto: Mater. Trans., JIM 31 (1990) $177-183$.

7) A. Peker and W. L. Johnson: Appl. Phys. Lett. 63 (1993) 2342-2344.

8) A. Inoue and S. G. Gook: Mater. Trans., JIM 36 (1995) 1180-1183.

9) A. Inoue, N. Nishiyama and T. Matsuda: Mater. Trans., JIM 37 (1996) 181-184.

10) T. Itoi and A. Inoue: Mater. Trans., JIM 41 (1999) 1256-1261.

11) X. H. Lin and W. L. Johnson: J. Appl. Phys. 78 (1995) 5614-5619.

12) S. Yi, T. G. Park and D. H. Kim: J. Mater. Res. 15 (2000) 2425-2430.

13) A. Inoue, W. Zhang and T. Zhang: Mater. Trans. 43 (2002) 1952-1956.

14) T. Zhang and A. Inoue: Mater. Trans. 43 (2002) 708-711.

15) W. Zhang and A. Inoue: Scr. Mater. 48 (2003) 641-645.

16) W. Zhang and A. Inoue: Mater. Trans. 43 (2002) 2342-2345.

17) H. Choi-Yim, D. Xu and W. L. Johnson: Appl. Phys. Lett. 82 (2003) 1030-1032.

18) A. Inoue, W. Zhang. T. Zhang and K. Kurosaka: Mater. Trans. 42 (2001) 1149-1151.

19) A. Inoue, W. Zhang, T. Zhang and K. Kurosaka: Acta Mater. 49 (2001) 3645-3652.

20) A. Inoue, W. Zhang, T. Zhang and K. Kurosaka: J. Mater. Res. 16 (2001) 2836-2844.

21) H. Kato and A. Inoue: Mater. Trans., JIM 38 (1997) 793-800.

22) W. L. Johnson: MRS. Bull. 24 (10) (1999), 42-56.

23) A. Inoue, W. Zhang, T. Zhang and K. Kurosaka: Mater. Trans. 42 (2001) 1805-1812.

24) A. Inoue, T. Zhang, K. Kurosaka and W. Zhang: Mater. Trans. 42 (2001) 1800-1804.

25) T. Zhang, T. Yamamoto and A. Inoue: Mater. Trans. 43 (2002) 32223226.

26) T. Yamamoto, C. Qin, T. Zhang, K. Asami and A. Inoue: Mater. Trans. 44 (2003) 1147-1152.

27) C. Qin, K. Asami, T. Zhang, W. Zhang and A. Inoue: Mater. Trans. 44 (2003) 749-753.

28) C. Qin, K. Asami, T. Zhang, W. Zhang and A. Inoue: Mater. Trans. 44 (2003) 1042-1045.

29) A. Inoue and W. Zhang: Mater. Trans. 43 (2002) 2921-2925.

30) A. Inoue: Mater. Trans., JIM 36 (1995) 866-875.

31) A. Inoue: Acta Mater. 48 (2000) 279-306.

32) Metals Databook, ed. by Japan Ins. Metals, (Maruzen, Tokyo, 1983), p. 8 .

33) F. R. Boer, R. Boom, W. C. M. Mattens, A. R. Miedema and A. K. Niessen: Cohesion in Metals, (North-Holland, Amsterdam, 1988) p. 224-225.

34) H. S. Chen: Rep. Prog. Phys. 43 (1980) 353-432. 